\title{
CARP EDEMA VIRUS DISEASE IN SERBIA - A DISEASE OUT OF CONTROL
}

\author{
Vladimir Radosavljević1 ${ }^{*}$, Dimitrije Glišić1 ${ }^{1}$, Jelena Maksimović-Zorić1, \\ Ljubiša Veljović ${ }^{1}$, Ksenija Nešić ${ }^{1}$, Vesna Miličević ${ }^{1}$
}

${ }^{1}$ Scientific Veterinary Institute of Serbia, Belgrade, Republic of Serbia

\section{Abstract}

A poxvirus named carp edema virus (CEV) is the causative agent of carp edema virus disease (CEVD), which is an emerging disease of global concern that may cause high rates of morbidity and mortality in ornamental koi and common carp. Common carp (Cyprinus carpio) is the most important fish species for warm-water aquaculture in Serbia. CEVD was first detected in Serbia in 2017. During the 2017-2020 period, an increasing number of CEVD outbreaks in carp farms was reported. The carp were collected from farms in different regions of Serbia from 2017 to 2020 . The fish were sampled for disease diagnosis because they exhibited lethargy and anorexia, which eventually led to mortality. Mortality started with clinical signs of hypoxia and the fish swam slowly and were unresponsive. The gills were pale and covered with a thick mucus layer. In later stages of the disease, the lesions in the gills turned into a necrotizing form. A moderate to high amount of opportunistic freshwater bacteria were isolated from the gills of the diseased fish. By performing real-time PCR, CEV was detected in 38 samples of the diseased carp taken from 21 carp farms. These outbreaks further confirm the spread of CEVD and the need for practitioners to be vigilant in the event of an outbreak of this disease. To prevent further spreading of the disease, it is very important to introduce CEV testing before moving fish. To avoid further transmission of the virus to common carp populations in Serbia, the testing of CEV should become part of fish disease surveillance programs. Fish health service should be aware of the presence of CEV in Serbia which may result in high losses in carp aquaculture. Action should also be taken to prevent transmission of $\mathrm{CEV}$ to carp populations in open waters.

Key words: Carp edema virus disease, CEV, Cyprinus carpio

${ }^{1 *}$ Corresponding Author: vladimiradosavljevic@yahoo.co.uk 


\title{
EDEMSKA BOLEST ŠARANA U SRBIJI - BOLEST VAN KONTROLE
}

\author{
Vladimir Radosavljević ${ }^{1}$, Dimitrije Glišić ${ }^{1}$, Jelena Maksimović-Zorić1, \\ Ljubiša Veljović ${ }^{1}$, Ksenija Nešić ${ }^{1}$, Vesna Miličević ${ }^{1}$ \\ ${ }^{1}$ Naučni institut za veterinarstvo Srbije, Beograd, Republika Srbija
}

\section{Kratak sadržaj}

Poksvirus nazvan virus edemske bolesti šarana (CEV) je uzročnik edemske bolesti šarana, nove bolesti koja može prouzrokovati visok morbiditet i mortalitet šarana i ukrasnih koi šarana. Šaran (Cyprinus carpio) je najvažnija vrsta za toplovodnu akvakulturu u Srbiji. Edemska bolest šarana (EBŠ) je prvi put utvrđena u Srbiji 2017. godine. Tokom perioda od 2017 do 2020. godine uočen je veliki broj slučajeva pojave ove bolesti na šaranskim ribnjacima. Uzorci šarana su prikupljani sa ribnjaka u različitim regionima Srbije u periodu od 2017. do 2020. godine. Ribe su uzorkovane jer su pokazivale letargiju i anoreksiju, što je na kraju dovodilo i do uginuća, sa kliničkim znacima hipoksije. Škrge obolelih jedinki su bile blede i prekrivene gustim slojem sluzi. U uznapredovalim slučajevima, škržne lezije su postajale nekrotične. Iz škrga obolelih riba je izolovan umeren do veliki broj oportunističkih bakterija. Primenom PCR u realnom vremenu, CEV je otkriven u 38 slučajeva pojave bolesti u 21-om šaranskom ribnjaku. Novi slučajevi pojave bolesti potvrđuju širenje EBŠ u Srbiji. S obzirom da ribe mogu ostati nosioci ovog patogena, potrebno je primeniti odgovarajuće biosigurnosne mere na šaranskim ribnjacima u kojima je dokazana pojava ove bolesti. Da bi se sprečilo dalje širenje bolesti, veoma je važno uvesti CEV testiranje pri prometu prijemčivih vrsta riba. Da bi se izbeglo dalje širenje virusa na populacije šarana u Srbiji, kontrola prisustva CEV trebalo bi da postane deo programa nadzora bolesti riba. Nadležne službe u oblasti zdravstvene zaštite riba moraju biti svesne prisustva ovog oboljenja u Srbiji, s obzirom da ono može dovesti do značajnih gubitaka u akvakulturi šarana.

Ključne reči: edemska bolest šarana, CEV, Cyprinus carpio

\section{INTRODUCTION}

Common carp (Cyprinus carpio) is the most important fish in Serbian aquaculture, with annual production of approximately 11,000 tons (Marković et al. 2011). In order to maintain and intensify the production, one of the main 
goals is to prevent the occurrence and spreading of the diseases, which could limit the sustainability of fish production. With that goal, annual control of listed fish diseases, namely koi herpesvirus (KHV) and spring viremia of carp virus (SVCV) has been carried out. However, the occurrence and spread of a new disease which may significantly affect the health of carp is a disturbing fact which requires attention of all the parties involved in the production chain. Carp edema virus disease (CEVD) is an emerging disease considered to be a potential risk for the carp aquaculture and for global food security as well (Kurita et al. 2009; Way et al. 2017), with new data about its spread, economic and biological properties being published rapidly over the past few years (Rehman et al. 2020; Machat et al. 2021).

The first outbreak of a disease caused by carp edema virus (CEV) was reported in 1974 in Japan, and for long time this disease was detected exclusively in ornamental koi carp (Murakami et al. 1976), but recently it was confirmed as a causative agent of a disease in koi and common carp in Europe, USA and many Asian countries (Way et al. 2017; Marsella et al. 2021).

In common carp, the disease was initially detected in the United Kingdom and in the Netherlands in 2012 (Way and Stone 2013; Haenen et al. 2014). After the initial detections, the CEVD was reported in The Czech Republic and Poland in 2013 (Vesely et al. 2015; Matras et al. 2017), followed by Austria and Italy in 2014 (Lewisch et al., 2015; Pretto et al. 2015), Hungary in 2016 (Adamek et al. 2018a), Lithuania and Croatia in 2018 (Adamek et al. 2018b; Zrnčić et al. 2020), and Slovakia in 2019 (Matějíćková et al, 2020)

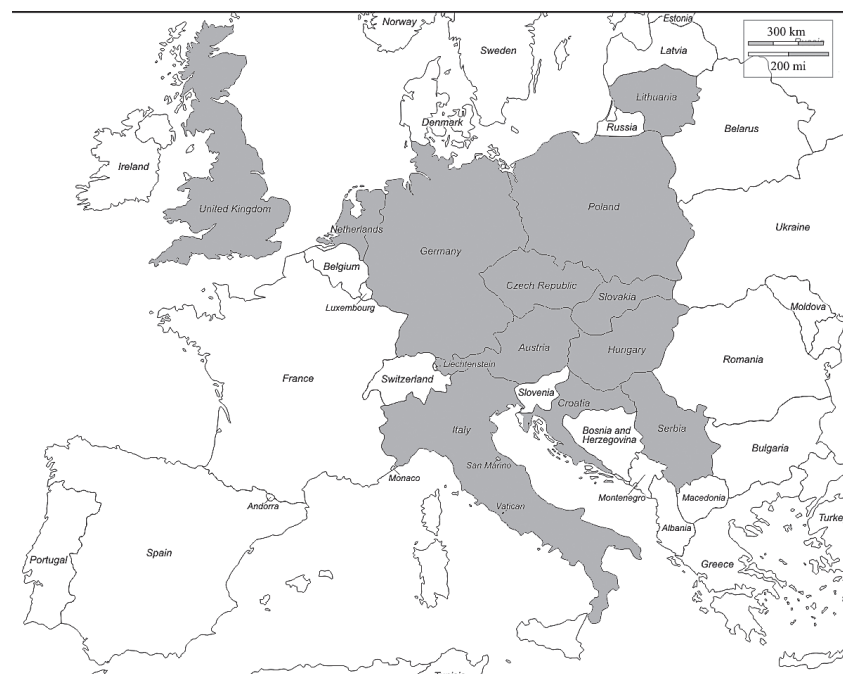

Figure 1. CEVD in common carp in Europe (map of Europe originated from https:// d-maps.com/continent.php?num_con=5\&lang=en) 
In the majority of cases, farmed common carp were involved. However, there are also reports of mortality events involving wild fish. For the first time in Europe, CEV was detected in wild common carp in Italy (Marsella et al. 2021). A wide temperature range from 6 to $24{ }^{\circ} \mathrm{C}$ has been recorded for the reported cases, although most of the outbreaks occurred at the temperature between 19 and $24^{\circ} \mathrm{C}$ (Divya et al. 2019). The disease generally has the characteristics of an acute infection at water temperatures between 15 and $25^{\circ} \mathrm{C}$, but it also occurs at a lower temperature $\left(6-10^{\circ} \mathrm{C}\right)$ when affecting common carp, resulting in a chronic infection characterized by a lower mortality (Lewisch et al. 2015; Way et al. 2017; Toffan et al. 2020).

Diseased fish become lethargic or show sleepy behavior and eventually die due to anoxia. The juvenile carp usually congregate near the surface of a pond or water inlet, whereas the older fish tend to stay at the bottom of the pond. The most frequently observed external lesions consist of increased skin mucous production, enophthalmos, erosion or hemorrhages at the base of the fin and gill necrosis (Way et al. 2017). Gross lesions in gills (hypertrophy, hyperplasia and lamellae clubbing) and subsequent necrosis of secondary gill lamellae may lead to the death of the infected fish (Machat et al. 2021).

Carp edema virus disease (CEVD) is caused by carp edema virus (CEV), which belongs to the subfamily Chordopoxvirinae in the Poxviridae family. CEV has double-stranded DNA genome and has a strong affinity to infect the gill epithelial cells. Phylogenetic analysis of the partial core protein $\mathrm{p} 4 \mathrm{a}$ has revealed the existence of three genogroups: I, IIa, and IIb showing $6-10 \%$ genetic diversity (Matras et al. 2017; Soliman et al. 2019).

Genogroup I consists exclusively of viral samples obtained from common carp collected mostly from European aquaculture countries, namely: The United Kingdom, Germany, Poland, Hungary and Balkan countries.

Genogroup IIa contains viruses isolated predominantly, but not exclusively from koi carp showing clinical signs of the disease with Asian and European isolates of the virus being included.

Genogroup IIb includes viral isolates from koi and common carp and was classified by phylogenetic analyses between the two aforementioned genogroups. The genogroup IIb is discovered in various carp samples in Poland (Matras et al. 2017).

The CEV spread is most probably the result of lack of availability of effective diagnostic and preventive measures in the global trade. The detection of the virus is difficult at subclinical level in specimen. Therefore, prevention of the disease is difficult and needs extra care at different stages such as transportation, transfer of fish from one pond to another, etc. It is likely that the establishment of an effective monitoring system and development of a highly specific diagnostic method could be helpful for the control of disease outbreaks 
(Rehman et al. 2020). Adequate measures for the prevention and disease control need to be taken in order to minimize the chances of disease outbreak such as avoiding transport and restocking of susceptible fish in different farming systems when the water temperature becomes suitable for virus replication (Sunarto et al. 2014). Also, CEV could have direct immunosuppressive effect on the host (Adamek et al. 2018a; Lewisch et al. 2015; Way et al. 2017), enabling secondary infections through impairment of gills (Adamek et al., 2018a). It is also mandatory to observe and isolate the susceptible fish to avoid further spread of CEV in stock.

Matras et al. (2019) showed that European perch (Perca fluviatilis) and five cyprinid species: tench (Tinca tinca), roach (Rutilus rutilus), bleak (Alburnus alburnus), crucian carp (Carassius carassius) and Prussian carp (Carassius gibelio) may serve as asymptomatic virus vectors, after cohabitation with $\mathrm{CEV}$ diseased carp. Adamek et al. (2016) suggested potential CEV persistence in carp and its stress-related reactivation. To prevent the introduction of pathogen in the stock, new fish should be kept in a separate area for at least 30 days at constant water temperature, and it should be taken care (feeding and daily routine maintenance). Further preventive measures include maintaining the fish health and providing quality water and feed while decreasing overcrowding and stress condition (Rehman et al. 2020).

Several methods can be used for CEV diagnostics, but the definitive proof of infection relies on the detection of viral DNA in tissues of the fish. The virus may prove difficult to detect at sub-clinical levels in apparently healthy survivors (Wey et al. 2017). Several cell lines were used for CEV isolation, but they were not successful (Swaminathan et al. 2016).

Currently, no treatment is available for CEVD. Different research showed that the mortality rate reduces the number CEV-infected carp when infected fish are immersed in $0.5 \%$ salted water.

After the first occurrence of carp edema virus disease (CEVD) in 2017 (Radosavljevic et al. 2018), an increasing number of CEV positive carp farms was detected. In this paper we report the increase in the incidence, disease in severity and mortality of CEVD at a carp farms during a four-year period, from 2017-2020.

\section{MATERIAL AND METHODS}

\section{Fish samples}

The carp were collected from 21 fish farms in different regions of Serbia from 2017 to 2020. The carp were sampled for disease diagnosis because the 
fish exhibited lethargy and anorexia, which eventually led to mortality. The total of 38 samples (the gill and kidney tissues of five individuals were pooled to form one sample) were examined including one-year-old (C1), two-year-old (C2) or three-year-old (C3) carps (5 fish from each group). External examination and sampling were performed for further investigation. After gill clipping and skin scraping, the presence of external parasite infection was inspected with an optical microscope. For bacterial culture, the organ surface was sterilized using a heated blade and punctured to perform parenchymal swab sampling. Bacterial cultures of the gills, liver, spleen, and kidney were kept for $48 \mathrm{~h}$ using tryptic soy agar plates at $20^{\circ} \mathrm{C}$. The gill and kidney tissue were sampled for virus isolation and DNA extraction.

\section{Virus isolation}

The post-mortem collected pooled gills and anterior kidney were homogenized in Earle's salt-based Minimal Essential Medium (MEM) (SigmaAldrich). The homogenate was inoculated in an array of cell lines (including CCB, EPC, BF-2, RTG-2, CHSE) for three passages, according to standard procedures.

\section{Molecular detection by PCR}

The samples were tested for CEV according to real-time PCR protocol described by Way et al. (2017). The sample RNA was extracted from the homogenates of the gill and anterior kidney tissues of diseased fish with the QIAamp Cador Pathogen Mini Kit (Qiagen), according to the manufacturer's instructions. The DNA was then stored at $-20{ }^{\circ} \mathrm{C}$ before PCR amplification. For detection of CEV p4a DNA, a probe-based qPCR assay developed by the Centre for Environment, Fisheries and Aquaculture Science (CEFAS) in Weymouth, UK (Adamek et al., 2017; Matras et al., 2017), was performed using the primers CEFAS_qF: AGTTTTGTAKATTGTAGCATTTCC, CEFAS_qR: GATTCCTC-AAGGAGTTDCAGTAAA and the double-labelled probe [FAM]-AGAGTTTGTTTCTTGCCATACAAACT-[BHQ1]. The amplification program included an initial denaturation at $95^{\circ} \mathrm{C}$ for $10 \mathrm{~min}$, followed by 40 cycles of denaturation at $95^{\circ} \mathrm{C}$ for $30 \mathrm{~s}$ and annealing at $60^{\circ} \mathrm{C}$ for $30 \mathrm{~s}$.

\section{RESULTS}

The total of 190 fish from 21 carp farms were examined, and 38 outbreaks of CEVD in common carp of various age were noticed in 6 regions in Serbia (Table 1, Figure 2). 


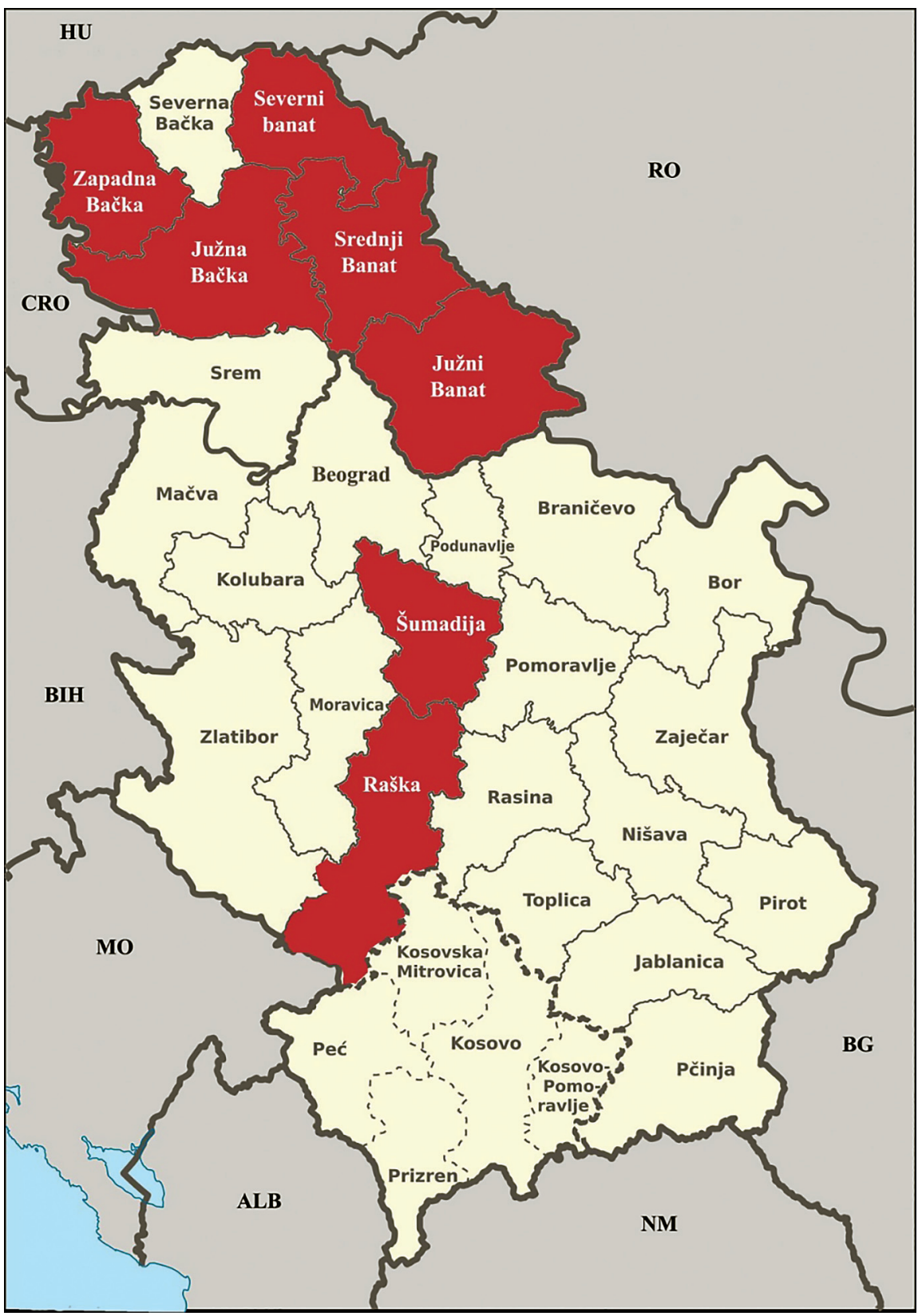

Figure 2. A map of Serbia showing districts with CEVD positive carp farms in red (map originated from: https://commons.wikimedia.org/wiki/File:Serbia_administrative_divisions_-_de_(districts).svg 
During CEVD outbreaks, no behavior changes or clinical signs of disease were noticed in other fish species present in the same pond with carp. Most outbreaks occurred between late spring and early summer, when water temperature was between $14^{\circ} \mathrm{C}$ and $25^{\circ} \mathrm{C}$. But, in a few cases, the occurrence of the disease with mortalities was noticed in autumn and early spring when temperature was just $7-12^{\circ} \mathrm{C}$ (Table 1 ). The highest mortality rates were recorded during an outbreak at the beginning of May (with water temperature of $18^{\circ} \mathrm{C}$ ) and during three outbreaks in September (water temperature $21^{\circ} \mathrm{C}$ and $22^{\circ} \mathrm{C}$ ) (Table 1). Various clinical signs of the disease were observed in CEV positive carps (Figure 3).

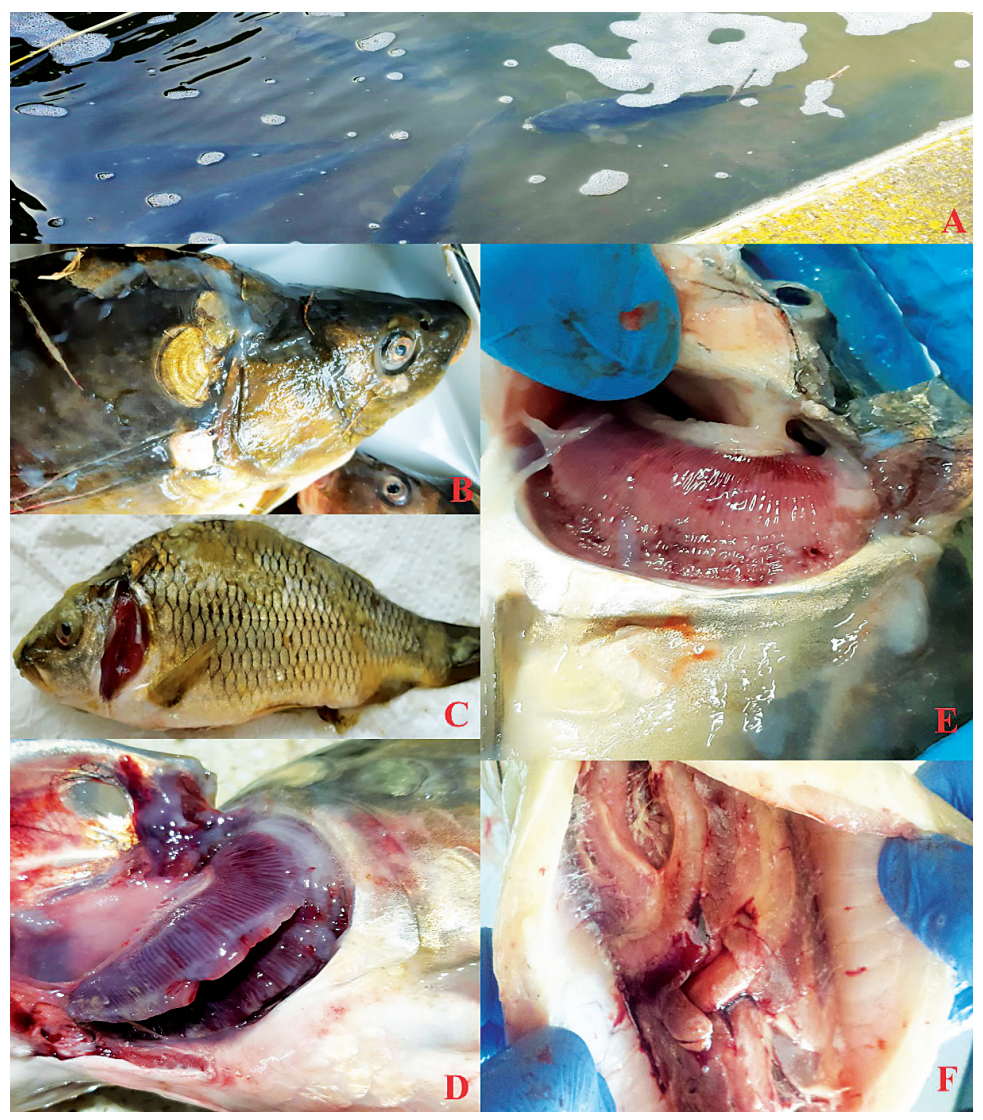

Figure 3. External examination and gross pathology of the carp: A) Lethargic behavior with reduced food intake; B) Overproduction of mucus on skin; C) Secondary bacterial and fungal gill and skin infections; D) Overproduction of mucus on gills; E) Pale swollen gills, sometimes with irregular discoloration and gill necrosis; F) Fibrinous peritonitis. 
Usually, fish farmers reported an increasing mortality of the fish that were unresponsive, gasping for air and swimming slowly.

Dominant clinical signs noticed during CEVD episodes includes:

1. Lethargic behavior with reduced food intake (Figure 3A).

2. Various cumulative mortality - mostly low $<20 \%$, but in severe cases $>$ $50 \%$.

3. Overproduction of mucus on gills and skin (Figures 3B, 3D).

4. Pale swollen gills, sometimes with irregular discoloration and gill necrosis, but never as drastic as with KHVD (Figure 3E).

5. No pathologies in internal organs, except fibrinous peritonitis (Figure 3F).

6. Various secondary bacterial and fungal gill and skin infections (motile aeromonads, pseudomonads, Flavobacteriae, B. mucoides, Saprolegnia spp, Branchiomyces spp.) (Figure 3C).

Table 1. CEVD outbreaks in Serbia between 2017 and 2020 in one-year-old (C1), two-year-old (C2) or three-year-old (C3) carps

\begin{tabular}{|c|c|c|c|c|c|}
\hline $\begin{array}{c}\text { Isolate } \\
\text { no. }\end{array}$ & Year & $\begin{array}{c}\text { Sample } \\
\text { name }\end{array}$ & $\begin{array}{c}\text { Location } \\
\text { District }\end{array}$ & $\begin{array}{c}\text { Facility } \\
\text { no. }\end{array}$ & $\begin{array}{c}\text { Case details } \\
\text { Month/water } \mathrm{T} \\
\% \text { mortality, age of fish }\end{array}$ \\
\hline 1 & 2017 & 3405 & Južnobački & 1 & May beg. $14^{\circ} \mathrm{C} /$ Low $\leq 20 \% / \mathrm{C} 1$ \\
\hline 2 & 2017 & 3406 & Južnobanatski & 2 & May beg. $15^{\circ} \mathrm{C} /$ Low $\leq 20 \% / \mathrm{C} 1$ \\
\hline 3 & 2017 & 3407 & Zapadnobački & 3 & May beg. $16^{\circ} \mathrm{C} /$ Low $\leq 20 \% / \mathrm{C} 1$ \\
\hline 4 & 2017 & 2775 & Južnobanatski & 4 & May beg. $17^{\circ} \mathrm{C} /$ Low $\leq 20 \%$ / C1 \\
\hline 5 & 2017 & 3386 & Raški & 5 & May beg. $18^{\circ} \mathrm{C} /$ High $\geq 50 \% / \mathrm{C} 1$ \\
\hline 6 & 2017 & 3394 & Severnobanatski & 6 & May beg. $16^{\circ} \mathrm{C} /$ Low $\leq 20 \% / \mathrm{C} 1$ \\
\hline 7 & 2017 & 3900 & Srednjebanatski & 7 & May end $18^{\circ} \mathrm{C} /$ Low $\leq 20 \% / \mathrm{C} 1$ \\
\hline 8 & 2018 & 2820 & Šumadijski & 8 & April beg $8{ }^{\circ} \mathrm{C} /$ Low $\leq 20 \% / \mathrm{C} 1$ \\
\hline 9 & 2018 & 2885 & Srednjebanatski & 7 & April end $9{ }^{\circ} \mathrm{C} /$ Low $\leq 20 \%$ / C2 \\
\hline 10 & 2018 & 4600 & Južnobački & 9 & July beg. $23^{\circ} \mathrm{C} /$ Low $\leq 20 \%$ / C3 \\
\hline 11 & 2018 & 4698 & Srednjebanatski & 10 & July beg. $25^{\circ} \mathrm{C} /$ Low $\leq 20 \%$ / C2 \\
\hline 12 & 2018 & 4997 & Južnobanatski & 4 & July beg. $24^{\circ} \mathrm{C} /$ Low $\leq 20 \%$ / C1 \\
\hline 13 & 2019 & 3578 & Srednjebanatski & 7 & April beg. $8^{\circ} \mathrm{C} /$ Low $\leq 20 \% / \mathrm{C} 1 \& \mathrm{C} 2$ \\
\hline 14 & 2019 & 3659 & Severnobanatski & 11 & April beg. $7^{\circ} \mathrm{C} /$ Low $\leq 20 \% / \mathrm{C} 1 \& \mathrm{C} 2$ \\
\hline 15 & 2019 & 3861 & Južnobački & 12 & April beg. $16^{\circ} \mathrm{C} /$ Low $\leq 20 \% / \mathrm{C} 1$ \\
\hline 16 & 2019 & 4550 & Severnobanatski & 13 & May end $18^{\circ} \mathrm{C} /$ Low $\leq 20 \%$ / C1 \& C2 \\
\hline 17 & 2019 & 4556 & Srednjobanatski & 10 & May end $17^{\circ} \mathrm{C} /$ Low $\leq 20 \% / \mathrm{C} 1$ \\
\hline 18 & 2019 & 4592 & Južnobanatski & 14 & May end $17^{\circ} \mathrm{C} /$ Low $\leq 20 \% / \mathrm{C} 2$ \\
\hline 19 & 2019 & 4683 & Srednjobanatski & 10 & June beg. $18^{\circ} \mathrm{C} /$ Low $\leq 20 \%$ / C1 \\
\hline 20 & 2019 & 4706 & Srednjobanatski & 15 & June beg. $17^{\circ} \mathrm{C} /$ Low $\leq 20 \%$ / C1 \& C2 \\
\hline 21 & 2019 & 6771 & Zapadnobački & 16 & Sept beg. $19^{\circ} \mathrm{C} / \mathrm{Med} 20-50 \% / \mathrm{C} 1$ \\
\hline
\end{tabular}




\begin{tabular}{|c|c|c|c|c|c|}
\hline $\begin{array}{c}\text { Isolate } \\
\text { no. }\end{array}$ & Year & $\begin{array}{c}\text { Sample } \\
\text { name }\end{array}$ & $\begin{array}{c}\text { Location } \\
\text { District }\end{array}$ & $\begin{array}{c}\text { Facility } \\
\text { no. }\end{array}$ & $\begin{array}{c}\text { Case details } \\
\text { Month/water } \mathrm{T} \\
\% \text { mortality, age of fish }\end{array}$ \\
\hline 22 & 2019 & 6844 & Severnobanatski & 11 & Sept beg. $19^{\circ} \mathrm{C} /$ Low $\leq 20 \%$ / C2 \\
\hline 23 & 2019 & 6874 & Zapadnobački & 17 & Sept beg. $22^{\circ} \mathrm{C} /$ High $\geq 50 \% / \mathrm{C} 1 \& \mathrm{C} 2$ \\
\hline 24 & 2019 & 6977 & Južnobački & 18 & Sept end $21^{\circ} \mathrm{C} / \mathrm{High} \geq 50 \% / \mathrm{C} 1$ \\
\hline 25 & 2019 & 7022 & Zapadnobački & 19 & Sept beg. $19^{\circ} \mathrm{C} /$ Low $\leq 20 \% / \mathrm{C} 1$ \\
\hline 26 & 2019 & 7168 & Srednjebanatski & 7 & Sept beg. $18^{\circ} \mathrm{C} /$ Low $\leq 20 \% / \mathrm{C} 1$ \\
\hline 27 & 2019 & 7279 & Srednjebanatski & 7 & Sept end $20^{\circ} \mathrm{C} /$ Low $\leq 20 \% / \mathrm{C} 1$ \\
\hline 28 & 2019 & 7331 & Srednjebanatski & 15 & Sept end $19^{\circ} \mathrm{C} /$ Low $\leq 20 \% / \mathrm{C} 1$ \\
\hline 29 & 2019 & 7427 & Zapadnobački & 19 & Oct beg. $16 /{ }^{\circ} \mathrm{C} /$ Low $\leq 20 \% / \mathrm{C} 1$ \\
\hline 30 & 2019 & 7724 & Zapadnobački & 19 & Oct end $14^{\circ} \mathrm{C} /$ Low $\leq 20 \% / \mathrm{C} 1$ \\
\hline 31 & 2020 & 2653 & Zapadnobački & 3 & April end $12^{\circ} \mathrm{C} /$ Low $\leq 20 \% / \mathrm{C} 1$ \\
\hline 32 & 2020 & 2902 & Severnobanatski & 11 & May beg. $15^{\circ} \mathrm{C} /$ Low $\leq 20 \% / \mathrm{C} 1$ \\
\hline 33 & 2020 & 2939 & Severnobanatski & 11 & May end $16^{\circ} \mathrm{C} /$ Low $\leq 20 \% / \mathrm{C} 3$ \\
\hline 34 & 2020 & 2973 & Srednjebanatski & 20 & May end $16^{\circ} \mathrm{C} /$ Low $\leq 20 \% / \mathrm{C} 2$ \\
\hline 35 & 2020 & 3316 & Zapadnobački & 19 & May end $15^{\circ} \mathrm{C} /$ Low $\leq 20 \% / \mathrm{C} 1$ \\
\hline 36 & 2020 & 3573 & Zapadnobački & 16 & June beg. $19^{\circ} \mathrm{C} /$ Low $\leq 20 \% / \mathrm{C} 1$ \\
\hline 37 & 2020 & 9299 & Zapadnobački & 16 & Oct end $13{ }^{\circ} \mathrm{C} /$ Low $\leq 20 \%$ / C2 \\
\hline 38 & 2020 & 10231 & Zapadnobački & 21 & Nov end $7{ }^{\circ} \mathrm{C} /$ Low $\leq 20 \% / \mathrm{C} 2$ \\
\hline
\end{tabular}

Besides these, various clinical signs were noticed in individuals, including sunken eyes, hyperemia or hemorrhages at fin base, fibrinous peritonitis, the perianal region, and the abdominal body surface, gill hemorrhages, skin erosions and ulcerations. In majority of the cases, the bacteria were not isolated from internal organs (liver, kidney and spleen), but always present on gills and skin lesions of the affected fish.

By performing real-time PCR, CEV was detected in samples from 38 outbreaks of disease from 21 carp farms.

No cytopathic effect was observed in five cell lines (CCB, EPC, BF-2, RTG2 , and FHM) following inoculation of filtrate from gill and kidney tissue homogenate of CEV positive carp, after 10 days of inoculation and even after three blind passages.

\section{DISCUSSION}

The present study revealed that CEV was widespread in Serbian common carp farms and the virus was detected during 38 outbreaks on 21 carp farms. After first detection of CEV in 2017 (Radosavljevic et al. 2018), a significant increase of CEVD cases was detected in 2019 and 2020. The number of CEV positive carp farms is probably underrated, since the disease was detected in 
all carp farms after sampling initiated by the owner, following occurrence of unexplained mortality in carp population.

The clinical signs and lesions observed in carp during the disease episodes in Serbia were consistent with previous reports (Way \& Stone 2013; Lewisch et al. 2015; Machat et al. 2021). The prominent clinical signs present during CEVD episodes in all the cases reported here are increased gill and skin mucous production with gill edema. Gills are the most vulnerable organ, displaying lamellae hypertrophy and hyperplasia, with consequent gaseous exchange impairment (Toffan et al. 2020).

Water temperature is a significant factor for development of CEVD. The disease in common carp has been reported at water temperatures between 7 and $15^{\circ} \mathrm{C}$ (Lewisch et al. 2015), and also at lower water temperatures between 6 and $9{ }^{\circ} \mathrm{C}$ (Way and Stone, 2013). Important predisposing factor is rapid temperature change and primary rapid rise in temperature. A majority of detected CEVD outbreaks in Serbia occurred when water temperature ranged between 13 and $24{ }^{\circ} \mathrm{C}$, but in 5 cases, the disease occurred between 7 and $12{ }^{\circ} \mathrm{C}$. This corresponds with findings of other authors (Lewisch et al. 2015; Divya et al. 2019; Toffan et al. 2020). Although underestimated and less frequently recognized, it is known that CEV infection can cause juvenile mortality up to 75 - 100\% (Toffan et al. 2020). The cumulative mortality rate in majority of the cases described here (34 out of 38 ) was below $20 \%$, but in three outbreaks, the mortality was higher than 50\%, and in one outbreak around $35 \%$.

In 17 outbreaks, co-infection with bacteria or fungi was present, as reported by other authors (Way et al. 2017; Machat et al. 2021). These isolated bacteria and fungi are known to be opportunistic pathogens for carp, and they had probably contributed to increase the severity of the disease.

No cytopathic effect was observed in five cell lines following inoculation of filtrates of gill and kidney homogenate of CEV positive carp, after three blind passages. The results are in accordance with earlier reports, where the virus was not isolated on various cell lines (Oyamatsu et al. 1997; Jung-Schroers et al. 2015; Swaminathan et al. 2016).

Having in mind an obvious increase in the number of CEVD cases in common carp and spread to new locations, adequate measures which will enable timely detection of the causative agent in infected fish and possible vectors should be adopted as soon as possible, since there are still many unsolved questions regarding potential asymptomatic vector species, modes of transmission, virus isolation, etc.

The emergence of infectious diseases is usually triggered by ecological changes, often associated with human interventions, such as transfer of organ- 
isms, environmental degradation, agricultural practices or technology (Jones et al. 2008). Introduction of new pathogens into naive populations can cause mass mortalities, as happened with common carp after introduction of KHV and with Prussian carp after introduction of CyHV-2. Usually, the first data about occurrence of new disease comes from fish in aquaculture, and the acquired data should be used as valuable information for prediction of the impact of the disease on susceptible free-living fish populations. Based on the presented information, it is obvious that there is a need for adequate legislation in order to control and prevent further spread of the virus. The implementation of control measures which will slow the spread of the disease is needed urgently, having in mind that $\mathrm{CEV}$ is detected in wild common carp populations in Europe and USA (Lovy et al. 2018; Marsella et al. 2021), and in asymptomatic fish hosts (Matras et al. 2019), which can significantly contribute to further spread of the disease.

\section{CONCLUSION}

CEVD is slowly becoming one of the biggest threats to carp aquaculture, due to increasing mortality in infected fish, and also due to reduced growth and the fact that secondary bacterial and fungal infections are regularly found in diseased fish, causing additional pathologies and mortality. Fish health service should be aware of the presence of CEVD, which may result in substantial losses in carp aquaculture. Based on the great importance of carp aquaculture in Serbia, a detailed surveillance and control program for CEVD is warranted, especially due to absence of international regulations regarding this disease. Internal movements of carp between aquaculture facilities are of particular concern because large numbers of live carp are moved and, since infections in aquatic animals are frequently subclinical, they would not be directly noticed before, during and immediately after the movement of the infected fish. Having in mind that movement of live aquatic animals always carries a risk of transferring aquatic animal pathogens, the controls should also involve internal fish movements between carp farms. In addition, disease quarantine inspections of imported/exported fish should be performed with greater precision. The quarantine procedure for CEVD should be performed in such way that carp is quarantined for a minimum of 30 days in the water with a constant temperature (between 15 and $25^{\circ} \mathrm{C}$ ). In order to avoid the spread of CEV infections, testing carp for $\mathrm{CEV}$ should become part of fish disease surveillance program. 


\section{ACKNOWLEDGEMENT}

This work was funded by Serbian Ministry of Education, Science and Technological Development (contract number 451-03-9/2021-14/200030).

\section{Author's Contribution:}

VR and VM made contributions to concept and design of the study, they collected data and drafted the manuscript. DG and VM carried out the molecular diagnostic tests and prepared the alignment of nucleotide sequences and conducted the molecular genetic analysis. LJV carried out the data analysis. $\mathrm{VM}$ and $\mathrm{KN}$ revised the manuscript critically and together with VR prepared the final draft of the manuscript. All the authors read and approved the final manuscript.

\section{Competing interest}

The authors declare that they have no competing interests.

\section{REFERENCES}

1. Adamek M., Jung-Schroers V., Hellmann J., Teitge F., Bergmann S.M., Runge M., Kleingeld D.W., Way K., Stone D.M., Steinhagen D. 2016. Concentration of carp edema virus (CEV) DNA in koi tissues affected by koi sleepy disease (KSD). Diseases of Aquatic Organisms, 119, 3, 245-251. doi: 10.3354/dao02994.

2. Adamek M., Matras M., Jung-Schroers V., Teitge F., Heling M., Bergmann S.M., Reichert M., Way K., Stone D.M., Steinhagen D. 2017. Comparison of PCR methods for the detection of genetic variants of carp edema virus. Diseases of Aquatic Organisms, 126, 1, 75-81. doi: 10.3354/dao03152.

3. Adamek M., Teitge F., Jung-Schroers V., Heling M., Gela D., Piackova V., Kocour M., Steinhagen D. 2018a. Flavobacteria as secondary pathogens in carp suffering from koi sleepy disease. Journal of fish diseases, 41, 11, 1631-1642. doi: 10.1111/jfd.12872.

4. Adamek M., Baska F., Nienius D., Radosavljevic V., Zrnčić S., Brnić D., Oraić D., Steinhagen D. 2018b. Erste Nachweise des carp edema virus in Ungarn, Litauen, Kroatien und Serbien bestätigen eine sehr weite Verbreitung des Virus in Karpfenbeständen in Europa. In XVII Gemeinschaftstagung der deutschsprachigen Sektionen der EAFP zum Thema Fischkrankheiten, 3-5. October, Fribourg/Schweiz, P-10. 
5. Divya P., Vertika B., Kirty S., Jyotirmaya M., Pramoda Kumar S. 2019. A review of current understanding on carp edema virus (CEV): A threatful entity in disguise. International Journal of Fisheries and Aquatic Studies, $7,5,87-93$.

6. Haenen O, Way K, Stone D, Engelsma M. 2014. Koi sleepy disease found for the first time in koi carps in the Nether-lands. Tijdschrift Voor Diergeneeskunde, 139, 26-29.

7. Jones K. E., Patel N.G., Levy M.A., Storeygard A., Balk D., Gittleman J.L., Daszak P. 2008. Global trends in emerging infectious diseases. Nature, 451, 990-993. doi:10.1038/nature06536.

8. Jung-Schroers V., Adamek M., Teitge F., Hellmann J., Bergmann S.M., Schütze H., Kleingeld D.W., Way K., Stone D., Runge M., Keller B., Hesami S., Waltzek T., \& Steinhagen D. 2015. Another potential carp killer? Carp Edema Virus disease in Germany. BMC Veterinary Research, 11, 114. doi: 10.1186/s12917-015-0424-7.

9. Kurita J., Yuasa K., Ito T., Sano M., Hedrick R.P., Engelsma M.Y., Haenen O.L.M., Sunarto A., Kholidin E.B., Chou H.Y., Tung M.C., Peña L., Lio-Po G., Tu C., Way K., Iida T. 2009. Molecular epidemiology of koi Herpesvirus. Fish Pathology, 44, 2, 59-66. doi:10.3147/jsfp.44.59.

10. Lewisch E., Gorgoglione B., Way K., \& El-Matbouli M. 2015. Carp Edema Virus/Koi sleepy disease: An emerging disease in central-east Europe. Transboundary and Emerging Diseases, 62, 1, 6-12. doi:10.1111/ tbed.12293.

11. Lovy J., Friend S.E., Al-Hussinee L., Waltzek T.B. 2018. First report of carp edema virus in the mortality of wild common carp Cyprinus carpio in North America. Diseases of aquatic organisms, 131, 177-186. doi: 10.3354/ dao03296.

12. Machat R., Pojezdal L., Piackova V., Faldyna M. 2021. Carp edema virus and immune response in carp (Cyprinus carpio): Current knowledge. Journal of fish diseases, 44: 371-378. doi: 10.1111/jfd.13335.

13. Marković Z., Stanković M., Dulić Z., Živić I., Rašković B., Spasić M.., Poleksić V. 2011. Akvakultura i ribarstvo u Srbiji - stanje i potencijal. In Conference Proceesings, V. International Conference "Aquaculture \& Fishery", June 1-3. 2011, Faculty of Agriculture, Belgrade-Zemun, Serbia, 36-40.

14. Marsella A., Pretto T., Abbadi M., Quartesan R., Cortinovis L., Fiocchi E., Manfrin A., Toffan A. 2021. Carp edema virus-related mortality in wild adult common carp (Cyprinus carpio) in Italy. Journal of fish diseases, 44, 939-947. doi: 10.1111/jfd.13353.

15. Matějíčková K., Pojezdal L., Pokorová D., Reschová S., Piačková V., Palíková M., Veselý T., Papežíková I. 2021. Carp oedema virus disease outbreaks in 
Czech and Slovak aquaculture. Journal of fish diseases, 43, 971- 978. doi: 10.1111/jfd.13179.

16. Matras M., Borzym E., Stone D., Way K., Stachnik M., Maj-Paluch J., Palusinska M., Reichert M. 2017. Carp edema virus in Polish aquaculture evidence of significant sequence divergence and a new lineage in common carp Cyprinus carpio (L.). Journal of Fish Diseases, 40, 319-325. doi: 10.1111/jfd.12518.

17. Matras M., Stachnik M., Borzym E., Maj-Paluch J., Reichert M. 2019. Potential vector species of carp edema virus (CEV). Journal of Fish Diseases, 42, 959-964. doi:10.1111/jfd.13000.

18. Murakami Y., Shitanaka M., Toshida S., Matsuzato T. 1976. Studies on mass mortality of juvenile carp: about mass mortality showing edema. Bulletin Hiroshima Fresh Water Fisheries Experimental Station, 19-33.

19. Oyamatsu T., Hata N., Yamada K., Sano T., Fukuda H. 1997. An etiological study on mass mortality of cultured colorcarp juveniles showing edema. Fish Pathology, 32, 81-88. doi: 10.3147/jsfp.32.81.

20. Pretto T., Abbadi M., Panzarin V., Quartesan R., Manfrin A., Toffan A. 2015. Carp edema virus (CEV): first detection in Italy. In EAFP 17th International Conference on disease of fish and shellfish, Las Palmas de Gran Canaria, September 7-11., Poster P-119, p 343.

21. Radosavljevic V., Adamek M., Milicevic V., Maksimovic-Zoric J., Steinhagen D. 2018. Occurrence of two novel viral pathogens (CEV and CyHV-2) affecting Serbian cyprinid aquaculture and ichthyofauna. Journal of Fish Diseases, 41, 5, 851-854. doi:10.1111/jfd.12789.

22. Rehman T., Yin L., Latif M.B., Zhou Y., Wang K., Geng Y., Huang X., Chen D., Fang J., Chen Z., Guo H., Lai W., Ouyang P. 2020. Current findings on carp edema virus, control challenges, and future outlook. Aquaculture International, 28, 2015-2026. doi:10.1007/s10499-020-00573-6.

23. Soliman H., Lewisch E., El-Matbouli M. 2019. Identification of new genogroups in Austrian carp edema virus isolates. Diseases of Aquatic Organisms, 136, 2, 193-197. doi:10.3354/dao03408.

24. Sunarto A., McColl K. A., Crane M. S., Schat K. A., Slobedman B., Barnes A. C., Walker P. J. 2014. Characteristics of cyprinid herpesvirus 3 in different phases of infection: implications for disease transmission and control. Virus research, 188, 45-53. doi:10.1016/j.virusres.2014.03.024.

25. Swaminathan, T. R., Kumar, R., Dharmaratnam, A., Basheer, V. S., Sood, N., Pradhan, P. K., Sanil N. K., Vijayagopal P., Jena J. K. 2016. Emergence of carp edema virus in cultured ornamental koi carp, Cyprinus carpio koi, in India. Journal of General Virology, 97, 12, 3392-3399. doi:10.1099/ jgv.0.000649. 
26. Toffan A., Marsella A., Abbadi M., Abass S., Al-Adhadh B., Wood G., Stone D. M. et al. 2020. First detection of koi herpesvirus and carp oedema virus in Iraq associated with a mass mortality in common carp (Cyprinus carpio). Transboundary and Emerging Diseases, 67, 523-528. doi:10.1111/ tbed.13428.

27. Vesely T, Pokorova D, Reschova S, Piačková V. 2015. Detection of carp edema virus in common carp (Cyprinus carpio) and koi carp in the Czech Republic. In EAFP 17th International Conference on disease of fish and shellfish, Las Palmas de Gran Canaria 7-11 September, European Association of Fish Pathologists, Poster P-122, p. 346.

28. Way K., Haenen O., Stone D., Adamek M., Bergmann S. M., Bigarré L., Diserens N., El-Matbouli M., Gjessing M. C., Jung-Schroers V., Leguay E., Matras M., Olesen N. J., Panzarin V., Piačková V., Toffan A., Vendramin N., Veselý T., \& Waltzek T. 2017. Emergence of carp edema virus (CEV) and its significance to European common carp and koi Cyprinus carpio. Diseases of Aquatic Organisms, 126(2), 155-166. https://doi.org/10.3354/ dao03164

29. Way K. and Stone D. 2013. Emergence of carp edema virus-like (CEV-like) disease in the UK. Finfish News, 15, 32-35.

30. Zrnčić S., Oraić D., Zupičić I. G., Pavlinec Ž., Brnić D., Rogić Ž. A., Sučec I., Steinhagen D., \& Adamek M. 2020. Koi herpesvirus and carp edema virus threaten common carp aquaculture in Croatia. Journal of Fish Diseases, 43, 6, 673-685. doi: 10.1111/ jfd.13163.

Received: 21.04.2021.

Accepted: 22.07.2021. 